\title{
A Program Designed to Empower Engineering Educators
}

\author{
Melany M. Ciampi \\ Safety, Health and Environment Research Organization \\ São Paulo, Brazil \\ melany@copec.org.br
}

Luis Amaral

Computer Graphics Center

Guimarães, Portugal

amaral@dsi.uminho.pt

Victor F. A. Barros

Science and Education Research Council

Braga, Portugal

victor@,copec.org.br

\author{
Claudio da Rocha Brito \\ Science and Education Research Council \\ São Paulo, Brazil \\ cdrbrito@copec.org.br
}

\author{
Rosa Vasconcelos \\ University of Minho \\ Guimarães, Portugal \\ rosa@det.uminho.pt
}

\begin{abstract}
Utilizing emerging technologies to provide expanded learning opportunities is critical to the success of future generations. So teachers have to be prepared to motivate and entice the students about getting knowledge pertinent for their formation as engineers. This paper describes the "International Engineering Educator" developed by the engineering education research team of COPEC - Science and Education Research Council. It is offered by the International Institute of Education of COPEC, which is a certification organization in accordance with the Ministry of Education of the Country referring to the National Law of Higher Education. It also offers a professional register as "International Engineering Educator" of the International Society for Engineering Pedagogy for those who are interested in such certification as something else. The target attendees for this program are the engineering community of CPLP - Community of Portuguese Language Countries. It is successful and many interested professionals are attending the program.
\end{abstract}

Keywords- On line technology; cultural skills; innovation; global vision; leadership.

\section{INTRODUCING}

It is a fact that most of the engineers in education field at the moment are engineers with a $\mathrm{PhD}$ or Master degrees. This does not mean that the professional has all the tools to be a proper teacher and now more than ever, once we have students with peculiarities that were unthinkable not long ago.

No matter the field, students are facing exchanges in the world, which characteristics have consequences for their formation, as happens with engineers. One of them is the constant change in the way people develop the work. This aspect is enhanced by the quick and strong technology development. Students today require more advice than properly information acquisition once information is now available any time any place in a huge amount, apart from the ability to be connected all the time. Students should know how to use educational technologies to apply knowledge to new situations, analyze information, collaborate, solve problems, and make decisions [1].

It is necessary to have in mind and realize that teachers now use emerging technologies to provide expanded learning opportunities for future generations' knowledge achievement. So teachers have to prepare themselves to motivate and entice the students on how to get knowledge pertinent for their formation as engineers. So it is possible to state that the use of new technologies in classroom is also an important requirement for teachers in Higher Education, specially in Engineering. It is part of teaching environment and therefore it is necessary to understand the environment of a young pupil. It is clear that life long learning environment is not only for future engineers but also for teachers.

\section{Higher EDUCATION AND ITS PHILOSOPHICAL AsPECTS}

More than ever, education is a key factor for economic success of a nation, as well as personal satisfaction, social stability everywhere and for all levels of society, age groups and subject area.

A philosophical aspect of present education environment however states that it is subjected to the capitalist work demands. It means that schools and universities are exposed to the interests of work market dictated by the capitalism 
environment ruled by private sector. The ideals of employability and entrepreneurship have the goal to convince people that they are free as the capitalists as long as they are "their own bosses". Through this perspective, the competences required by present higher education demand the formation of a professional which main aspect is that $\mathrm{s} /$ he has to be capable to know how to be and not so much about the amount of knowledge that $\mathrm{s} /$ he has [2].

Therefore, taking into account the present historical moment, preparing a professional means preparing them for the employability and entrepreneurship which main requirement, besides the pertinent knowledge, is the "know how to be", i.e., the capability to develop personal skills that provide adaptability, flexibility and problem solve mind.

Under this perspective educators are considered the ones responsible for the preparation of citizens according to the values, skills and knowledge that the capital needs.

Anyway, this paradigm of education busted by technology resources is shaping a different kind of education requiring a different kind of educator who, apart from philosophical discussions, has to survive in this extremely competitive market in a global scale.

This means a deep change in the role and profile of educators. This change leads to the following aspects:

- Time for activities that integrates the several disciplines

- Willing to learning altogether with the students and with the experience

- Challenge the students with complex tasks that enhance them to mobilize their knowledge

- To be aware that $\mathrm{s} / \mathrm{he}$ is a didactic situation organizer and also a buster of activities that are meaningful and pertinent for them.

In this sense, the role of an educator is not to transmit the knowledge accumulated by humanity; the emphasis of the educational action of educators is to provide the students with tools that help them to understand the world and so to act on it [3].

In this new context, educators have a deep influence in the way education is being developed in classroom. The educators have now to master the art of entice and foster students to pursue a career that is really meaningful for them and to be the best, otherwise it would be very difficult to survive in the work market. It also means that the professional has in her/his hands the possibility to master her/his career despite the historical moment and no matter the work market.

\section{ENGINEERING EDUCATOR SKILLS}

Knowledge of engineering is an important factor for the new educator as well as to develop some competencies as any professional who has to compete and achieve success in the career.

Besides having the solid knowledge about her/his field of expertise, the engineering professor is expected to have some competences such as:
- Interpersonal skills, which mean to be able to interact with students, listen to them and get information to boost the learning process;

- To be capable of developing a collaborative work environment;

- Leadership and ethical behavior that shows respect;

- Always prepare the classes with organization and didactic;

- To be innovative, open minded for innovations that inspire students;

- Flexibility to accept new ideas and different kinds of personality;

- To be able to learn and make different use of evaluation;

- Global vision and capability of create conceptual models as a competitive differential.

A very important aspect is also that presently many institutions have developed programs to prepare the engineering professor to perform in order to be competitive as professional and to enhance education to form the citizen for this century of uncertainty and challenges [4].

It is not enough that universities as education institutions offer good curriculums, good labs and have top technology available in classroom because, in part, an important institutional competitiveness factor is also the teacher. Still the educator is a key factor for the success of any educational endeavor even in an environment where education is considered as business.

\section{Course Methodology}

This program is an adventure toward the discovery of new skills and the acquisition of new tools that will provide the opportunity to develop the capability of performing as educator, always following the new trends in education. Besides this is a program of international certification, which is also a new trend in global education.

It is a modular program, on line, with credits in ECTS with equivalent in hours in accordance to the educational legislation of the Country.

The certification in engineering education requires:

- $\quad$ each module of 60 hours or 12 ECTS

- $\quad$ so 3 modules that add up 180 hours or 36 ECTS [5].

The program is delivered $100 \%$ on line.

The program is delivered in Portuguese Language and the target audience is the engineers dedicated to the education and citizens of countries of Portuguese language.

The program is offered to the CPLP - Community of Portuguese Language Countries.

The program is being delivered and the feedback questionnaires answered by the participants are completed after every module conclusion. The numbers and percentages are being computed and by the end of 2014 the full results on satisfaction, relevance for career and impact in daily classroom 
performance are expected. A partial result given by present participants shows the program so far to be very much satisfactory. The flexibility in terms of content access has showed to be an important aspect once it gives a larger possibility of study. It is a point for further examination regarding not only information about quality and success of the program but also as a strategic asset for the future development of the program.

\section{LANGUAGE AND FORMATION}

Language is part of what we are. With more than 230 million native speakers, Portuguese is the fifth most spoken language in the world [6]. It is spoken in Europe, America, Africa and Asia.

Even in Europe, Portuguese is the third most spoken language, due to emigrant communities spread across the continent.

Portuguese is an official language of the European Union (former EEC) since 1986, date of the admission of Portugal in the Community. Due to the agreements of Mercosur (Southern Common Market), of which Brazil is a party, Portuguese is taught as a foreign language in other countries that participate in it.

In 1996, the Community of Portuguese Language Countries (CPLP), which brings together countries with Portuguese as the official language for the purpose of enhancing cooperation and cultural exchanges between the member countries and to standardize and disseminate the Portuguese language was created [7].

According to the Sapo Observatory, a language is a much more valuable asset the more partners and the more users it has. Language is a super public good, since the sharing increases its value. The economic power of Portuguese speakers represents $4 \%$ of global wealth.

About $50 \%$ of new oil and gas discoveries made since 2005 are located in countries of Portuguese Language. This will be a transformational factor of geopolitical importance of Portuguese in the global economy.

Indeed, this underlying trend was the cover story in a recent issue of the prestigious Monocle magazine, which ranked Portuguese as "the new global language of power and commerce".

In fact, according to the latest analysis from consultants IHS and Bernstein Analysis three Portuguese-speaking countries lead the ranking of the top 10 discoveries of oil and gas on the planet this decade [8].

\section{SCIENCE AND EDUCATION RESEARCH COUNCIL MAIN ASPECTS}

COPEC has become an international organization with a History that started with an idea shared by some scientists of creating an organization to foster the research mainly in sciences and education. This idea seized larger proportions and after some meetings the Council became reality. This is a group of scientists, professors and professionals whose vision of future has driven them to start this work.

The main mission of COPEC is to promote the progress of science and technology for the welfare of humanity.

Through its activities, COPEC maintains relations with universities, institutions of education, enterprises and the society of several countries for the discussion of sciences, technology and education directions.

COPEC - Science and Education Research Council has been very active and has developed many achievements of great importance for the Country in which it is located.

The Council is an organization constituted by scientists of several areas of human knowledge committed with education and the development of science and technology.

Its members believe that education is the main beam in the construction of a better society and that sciences and technology are the big agents in the fostering of progress to promote the welfare of human being [9].

It is an organization that is present now in Europe always working for the science and education enhancement targeting the development of a better human life promoting the social, ethical and educational values so important for human conditions in the planet.

\section{A PROGRAM TARGETING THE IMPROVEMENT OF EDUCATORS IN ENGINEERING FIELD}

COPEC - Sciences and Education Research Council main and proud mission is to promote the progress of science and technology for the welfare of the humanity.

The main objective is to promote an apprenticeship community and the development of education and sciences areas constituting an intelligent way of collective knowledge for the integration with social and economic agents of community [10].

COPEC is an organization that develops many activities in science and education. One of them is the IGIP National Monitoring Committee of Brazil, which provides the courses for engineering educators and has also a large experience developing and implementing engineering programs. The engineering education research team has decided to develop and to offer a specific program for engineers dedicated to education.

It is an international organization that has been preparing engineers educators in Europe for more than 34 years and now worldwide [11].

The whole process of offering the course originated in the initiative of both organizations that want to make engineering education training skills and practice targeting the international engineering educators.

For some years IIE COPEC Institution of Education has delivered the program in classroom. However, the number of people who could attend the program was very small once it happened in one geographical region of the country. With the development of on line technology to deliver programs and the 
possibility of reaching a much larger community the institution of education of COPEC decided to offer the program on line.

So the target participant has spread to countries of Portuguese language, which is a large portion of the planet and countries that are becoming economically important in global scenario.

The ministry of education at national level recognizes the certification. Internationally the certification is an INGPAED IGIP the International Society of Engineering Pedagogy [12].

\section{VIII.ADMISSION REQUIREMENTS}

As any graduation program candidates' requirements for admission are:

- Candidates should have at least master degree in science, engineering, or technology

- Professionals with other backgrounds are considered based on their interest, formal education and experience in teaching [13].

\section{The Program Modules}

Core Modules:

- Engineering Education in Theory

- Engineering Education in Practice

- Laboratory Didactics

Theory Modules

- Psychology

- Sociology

- Engineering ethics

Practice Modules

- Presentation and communication skills

- Scientific writing

- Working with projects

- ICT in engineering education

Elective Modules (up to the institutions that deliver the program)

- Intercultural competence

- Evaluation of student performance, grading and assessment

- Quality management

- Curriculum development

- CLIL - Content and Language Integrated Learning

- Portfolio assessment

- Creative thinking

- Collaborative work

- Coaching and mentoring

- Infoliteracy

\section{Program EXPeCted Outcomes}

There is no doubt that the most valuable result of this program is the quality of teachers prepared to adopt new styles in teaching and also learning [14]. Living is learning and teaching is learning as well, as the experience of teaching is a two ways path for the construction of knowledge.

The program fosters mainly some skills such as:

- Apply the new knowledge in classroom immediately;

- Generate new ideas, new ways of teaching;

- Learn with the students;

- Create a classroom environment based on confidence, ethic and teamwork.

It indeed helps the engineers educators to look at new styles of teaching as well as to pursue quality classes based on pertinent knowledge developing a two-way flow of information [15].

\section{FINAL DISCUSSIONS}

The program is the result of the efforts of COPEC Engineering Education Research team and is offered by its International Institute of Education.

The program has been designed in order to fit the necessities of professionals interested in the improvement of career and quality performance.

The choice to deliver it on line provides the opportunity for a larger audience of Portuguese language, in different countries.

Being a flexible program, it is developed in accordance to the needs for the accomplishment of the main goal: to form engineering educators prepared for the 21 st Century demands.

It has an impact in the academic community once it can provide engineers with the opportunity to update knowledge, as it is lifelong education environment from now on.

Besides being a valuable and rich program that provides tools for teaching, the engineering educator receives a certification that is recognized both national and internationally.

Another aspect noticed by the statistics is that, although the program is delivered in Portuguese, some people from Spanish language countries are attending the program. This indicates that the spectrum of on line courses can be even broader for those who, although the mother language is not Portuguese, can understand it in a level that allows them to study any subject.

The information basis for the development of this paper is the work besides the real experience of the members of the COPEC engineering education team. They have a large experience in developing research in engineering education besides the large experience in developing engineering programs for different engineering schools as well as the knowledge of the state of the art in engineering education. This is an international group of engineers dedicated to the development of engineering education internationally.

\section{ACKNOWLEDGMENT}

This work is funded by FEDER funds through the Operational Program for Competitiveness Factors 
(COMPETE) and National Funds through FCT - Foundation for Science and Technology under the Project: FCOMP-010124-FEDER-022674 and PEst-C/CTM/UI0264/2013.

\section{REFERENCES}

[1] http://www.dgrhe.min-edu.pt

[2] http://www.academia-engenharia.org/direscrita/ficheiros/ EngineeringEducationPortugal_FinalReport.pdf

[3] http://www.iadb.org/res/laresnetwork/files/pr294finaldraft.pdf

[4] http://www.iadb.org/res/publications/pubfiles/pubR-463.pdf

[5] Brito, C. da R.; Ciampi, M. M., Braga, M. S.; Braga, E. R. Green Lifestyle becoming the Men's New Way of Life. In: Safety, Health and Environmental World Congress, 14, Cubatão, 2014. Green Lifestyle becoming the Men's New Way of Life. Cubatão: SHERO, 2014.

[6] Brito, C. da R.; Ciampi, M. M.; Vasconcelos, R. M.; Amaral, L.; Barros, V. F. A. Environmental Engineering Program Preparing Engineers to Tackle New Challenges. In: IGIP Annual Symposium, 42., Kazan, 2012. The Global Challenges in Engineering Education. Kazan: IGIP, 2013.

[7] http://www.linguaportuguesa.ufrn.br/pt_3.php

[8] http://observatorio-Ip.sapo.pt/pt/geopolitica/o-valor-economico-dalingua-portuguesa/a-era-do-petroleo

[9] Brito, C. da R.; Ciampi, M. M.; Vasconcelos, R. M.; Amaral, L.; AlUbaidi, M. Engineering Education in a Technology-dependent World. In: International Conference on Engineering and Technology Education, 13, Guimarães, 2014. Engineering Education in a Technologydependent World. Guimarães: INTERTECH 2014.
[10] Brito, C. da R.; Ciampi, M. M. Technological Development, Sustainability: Discussions about International Aspects of Engineering Education. In: IEEE EDUCON Annual Conference, 01, Madrid, 2010. The Future of Global Learning in Engineering Education. Madrid: IEEE, 2010.

[11] Brito, C. da R.; Ciampi, M. M.; Vasconcelos, R. M.; Amaral, L.; Barros, V. F. A. Challenging Time for Engineering. In: American Society for Engineering Education Annual Conference, 120, Atlanta, 2013. 2013 ASEE Annual Conference Program \& Proceedinngs. Atlanta: ASEE, 2013.

[12] Brito, C. da R.; Ciampi, M. M. Forming Engineers for a Growing Demand. In: International Conference on Engineering and Computer Education, 8, Luanda, 2013. Forming Engineers for a Growing Demand. Luanda: ICECE, 2013.

[13] Brito, C. da R.; Ciampi, M. M.; Barros, V. F. A Innovative and Reliable Information Technology for a Sustainable World. In: World Congress on Systems Engineering and Information Technology, 01, Porto, 2013. Innovative and Reliable Information Technology for a Sustainable World. Porto: WCSEIT, 2013.

[14] Brito, C. da R.; Ciampi, M. M.; Vasconcelos, R. M.; Amaral, L.; Barros, V. F. A. Interdisciplinary Environmental Engineering Program. In: European Society of Engineering Education Annual Conference, 41, Leuven, 2013. Engineering Education Fast Forward. Leuven: SEFI, 2013.

[15] Brito, C. da R.; Ciampi, M. M.; Vasconcelos, R. M.; Amaral, L. Engineering Education in Countries of Portuguese Language. In: ASEE/IEEE Frontiers in Education Annual Conference, 43, Oklahoma City, 2013. Energigizing our Future. Oklahoma City: FIE, 2013. 